\title{
CONSUMER ACQUAINTANCE AND PERCEPTION ABOUT MOBILE WALLETS IN INDIAN URBAN CONSUMER MARKETS
}

\author{
Dr. Tejas Dave \\ Associate Professor, School of Liberal Studies, Pandit Deendayal Petroleum University, Gandhinagar, \\ Gujarat, India, Tejas.Dave@sls.pdpu.ac.in
}

\begin{abstract}
The Indian consumer markets have observed considerable growth in last two decades. The Information technology revolution has provided opportunities of market expansion to national and international companies in India. The new era is of $\mathrm{M}$-Commerce and mobile applications which have broken all barriers for markets in last two decades. Now point of sales (POS) locations is not important. The consumer can buy anything from anywhere in the world as the multiple online options are available with consumer. In last two decades, rapid urbanization has been observed in India. The purchasing power of urban consumer is also considerably improved in last one decade. There are many companies and financial institutions have realized opportunities in online payment platforms. To make it more convenient to consumers and market, many organizations have ventured into digital wallet business. They have received tremendous response from the urban and rural Indian markets in last four years. There are many reasons behind swift penetration of digital wallet market; one of them is brisk expansion of smartphone market in India with multiple brands from Europe, US and China. This paper mainly focuses on Indian urban markets and tries to understand and measure perception and preferences of consumers of urban India. The findings highlight the issues pertaining to supply chain realignment, on field application problem and financial implications of digital wallet. It also attempts to identify strategies pertaining to supply chain and marketing to make this platform more consumer and market centric.
\end{abstract}

Keywords: Supply Chain Integration, Strategic Alliance, M-Commerce, Digital Wallets

\section{INTRODUCTION}

The Indian economy has observed considerable growth in last 27 year after financial reforms of 1991. Today, the Indian markets are more open, competent and transparent for corporate. The size of the Indian economy is also considerably expanded and reached to 2.6 trillion dollar. (Yashwant Raj, 2018) Over the years, the India has gained confidence of global financial institutions and corporate and significant investment is being done by FDI. The India has secured $11^{\text {th }}$ rank in the global FDI confidence index 2018. (IBEF, 2018) The Indian markets are mainly divided into two parts; Urban and Rural. The Indian economy has also observed rapid urbanization in last two decades. The rural population is migrating to urban areas for better employment opportunities and also for the better life style. The poverty in rural areas is also one of the important factors behind rapid urbanization in India. (Neelmani Jaysawal \& Sudeshna Saha, 2014) The information technology revolution in last three 
decades has changed dynamics of world markets. The bargaining power has been shifted from manufacturer to consumers in global economy. The market of mobile phone and smartphone is being considerably expanded in India. The smartphone which was considered as luxury now recognized as a necessity specifically in urban Indian markets. The governments are also more emphasizing on online platform for communication and for the transaction. The smartphone industry has created opportunities for application developer IT companies. Looking at the need of the markets, now the apps are available in multiple languages which have made this market customer centric. The knowledge and competency of people specifically in urban India have considerably improved in smartphone applications. The mobile subscription rate is also exponentially expanded in India.

As per the ASSOCHAM report 2016, the mobile cellular subscription rate per 100 people is 77 in 2015, which was 44 in 2009. The November 2016 decision of Narendra Modi government of demonetization has benefited banks and other financial institutions in different ways. The primary purpose of the demonetization was to restrain corruption in the country. This move has encouraged citizens to do cashless transaction. The banks and other financial institutions are benefited and usage of credit card, debit cards, M-wallets and internet banking is being considerably expanded. The ASSOCHAM report 2016, indicates that approximately 100 million consumers are using e-wallets in their transaction. The report also says that the urban youth is more inclined towards cashless transaction. The central government is also very supporting in payment bank licensing. Numbers of telecom operators and third party payment service providers are applying for license. Looking at the long term potential, banks have adopted aggressive strategies to expand their credit card and debit card sales. The banks and their staff are now encouraging customers to do cashless transactions. Many banks have reduced rate of interest on credit cards. The Indian mobile payment market is divided into mainly three segments; mobile banking, mobile wallet and mobile POS. The mobile POS comprise debit card, credit card and gift card. Out of these three segments, the exponential growth has been observed in mobile segment because of its applicability in micropayment and also suitable for smaller outlets. The aggressive marketing strategies of the corporate and up gradation of telecommunication infrastructure are major reasons behind rapid penetration of $\mathrm{M}$-wallets market. (ASSOCHAM, 2016)

\section{MOBILE WALLETS}

The mobile wallets are basically application base and allow user to deposit their money in digital form. The user can use multiple methods to fill mobile wallets like online transaction, debit cards, credit cards etc. There are different types of mobile wallets options available for consumers depending upon their category i.e bank account holder \& non bank account holder. There are mainly four types of mobile wallets; open wallet, Semi-open wallet, closed wallet and semi closed wallet. (Sharon Devarajan, 2016)

\section{LITERATURE REVIEW}

The paper of Srihari Kulkarni and Abdul Shahanaz Taj (2017) highlights importance of digital transaction for corporate to cover urban and rural markets of India. The detailed discussion is made about different options of digital transaction and also discussed financial and commercial implication for Indian consumers and for the corporate. The research outcomes mainly communicate convenience part of digital payments. It also says that the usage of debit card and credit card is maximum compared to other modes of digital transaction. In the digital transaction, the transaction security is one of the most important areas for consumers. The lack of sensitivity of user towards updated security software applications like antivirus and spyware in digital devices is also important issue. The paper also emphasizes need of effective and efficient laws to maintain trust of consumers in digital payment system.

The research paper of Pushpa S. Abbigeri and Rajeshwari M. Shettar (2018) discusses various modes of digital payments, long and short term benefits of cashless economy and accessing readiness of government for cashless economy. The finding highlights the positive results of government initiatives for cashless economy. It also communicates about rapid information technology advancement specifically in wireless technology has provided support to cashless economy initiatives. The finding assumes that the government initiatives like demonetization and GST will ultimately enhance the size of the Indian economy in longer term. In suggestion part, the researchers recommend government to bring transparency and efficiency in e-payment system and also to withdraw service charges to motivate corporate and consumers to use digital modes in transaction. The paper also suggests government to take initiative to improve financial literacy of common citizen and also to educate them about micro and macro level benefits of cashless economy.

The paper of J.Mohamed Ali and L.Vijaya Gopalan (2018) presented different categories of the E-Wallets in first 
of the research paper. The SWAT analysis presented of the E-Wallet in reference to India in the second part. The financial inclusion, easy to use and accessibility of multiple accounts are the major strengths identified in SWAT analysis. The major weaknesses are lack of infrastructure, electricity problem specifically rural areas and E-illiteracy. At macro level the biggest development of active initiative by the government for cashless economy and this development will provide tremendous amount of opportunity to this industry. The researchers also assume that all these developments will break the parallel financial system and will transform economy in single main stream in longer period. The data and information security are the most important threats considered by the researcher in this business.

\section{SCOPE AND OBJECTIVES:}

The secondary data indicates that the market penetration of online mode of transaction is in rapid pace specifically in urban parts of India. In the Indian markets, all range of smartphones are available and catering the market needs of premium to economic segments. The online and mobile apps are used in almost all products and service categories in Indian urban markets like movie tickets, bill payment, recharge, shopping, equity trading, insurance, money transfer etc. The mobile wallet markets are also competitive, and newer and newer firms are entering into this market every month. For micro payments, the mobile wallets are now extremely competitive tool considered by the consumers.

The primary research mainly focuses on FMCG market and three industries named as FMCG consumable goods, FMCG household goods and FMCG personal care products. The research aims to fulfill following three objectives.

1. To understand attitude and likings of consumer towards online purchase of FMCG products.

2. To understand preferences in mode of transaction in purchase of FMCG products.

3. To understand opinion of consumer about mobile wallets as an application in commerce.

\section{RESEARCH DESIGN}

The cross sectional convenience sampling design is used for the primary research. The interview administered questionnaire was designed for data collection. Total 150 samples were targeted out of which 129 respondents have given their responses. For selected questions, chi square and one way ANOVA are used for hypothesis testing. The survey was conducted in Ahmedabad city. The responses were taken from people of all age groups; starting from 18 to above 61 . The people with smartphone are only included in primary research. The questionnaire is divided into three parts; the first part designed to understand buying preferences of consumers between offline and online markets. The second part is about preferences of consumers about mode of transaction in various FMCG categories and third part is to understand opinion about various issues pertaining to mobile wallet applications.

\section{DEVELOPMENT \& TESTING OF HYPOTHESES}

On the basis of literature review and the variable depicted above, the hypotheses developed are;

1. $H_{0}$ : Type of FMCG industry and frequency of purchase are independent

$\mathrm{H}_{1}$ : Type of FMCG industry and frequency of purchase are dependent

2. $\mathrm{H}_{0}$ : Type of FMCG industry and mode of payments are independent

$\mathrm{H}_{1}$ : Type of FMCG industry and mode of payments are dependent

3. $H_{0}$ : Usage of mobile wallets application is same in all three FMCG industries; Ho: $\mu_{F \& B}=\mu_{H H}=\mu_{P C}$

$\mathrm{H}_{1}$ : Usage of mobile wallets application is not same in all three FMCG industries; $\mathrm{H} 1: \mu_{\mathrm{F} \& \mathrm{~B}} \neq \mu_{\mathrm{HH}} \neq \mu_{\mathrm{PC}}$ 
IJASOS- International E-Journal of Advances in Social Sciences, Vol. V, Issue 13, April 2019

\begin{tabular}{|c|c|c|}
\hline $\begin{array}{l}\text { Sr. } \\
\text { No. }\end{array}$ & Statement & Result \\
\hline 1 & $\begin{array}{l}\mathrm{H}_{0} \text { : Type of FMCG industry and frequency of } \\
\text { purchase are independent } \\
\mathrm{H}_{1} \text { : Type of FMCG industry and frequency of } \\
\text { purchase are dependent }\end{array}$ & $\begin{array}{l}\text { Chi Square Test } \\
\text { Degree of freedom: } 8 \\
\text { Level of significance: } 0.05 \\
\text { Acceptance limit: } 15.507 \\
\text { Chi Square : } 104.18 \\
\text { Ho is rejected }\end{array}$ \\
\hline 2 & $\begin{array}{l}\mathrm{H}_{0} \text { : Type of FMCG industry and mode of payments } \\
\text { are independent } \\
\mathrm{H}_{1} \text { : Type of FMCG industry and mode of payments } \\
\text { are dependent }\end{array}$ & $\begin{array}{l}\text { Chi Square Test } \\
\text { Degree of freedom: } 10 \\
\text { Level of significance: } 0.05 \\
\text { Acceptance limit: } 18.307 \\
\text { Chi Square }: 26.44 \\
\text { Ho is rejected }\end{array}$ \\
\hline 3 & $\begin{array}{l}\mathrm{H}_{0} \text { : Usage of mobile wallets application is same in all } \\
\text { three FMCG industries; Ho: } \mu_{\mathrm{F} \& \mathrm{~B}}=\mu_{\mathrm{HH}}=\mu_{\mathrm{PC}} \\
\mathrm{H}_{1}: \text { Usage of mobile wallets application is not same in } \\
\text { all three FMCG industries; } \mathrm{H} 1: \mu_{\mathrm{F} \& \mathrm{~B}} \neq \mu_{\mathrm{HH}} \neq \mu_{\mathrm{PC}}\end{array}$ & $\begin{array}{l}\text { One way ANOVA } \\
\text { Numerator Degree of freedom: } 2 \\
\text { Denominator Degree of freedom: } 387 \\
\text { Level of significance: } 0.05 \\
\text { Acceptance limit:3 } \\
\text { F Statistic : } 34.45 \\
\text { Ho is rejected }\end{array}$ \\
\hline
\end{tabular}

\section{Hypothesis 1:}

The rejected null hypothesis indicates that the frequency of purchase in all three FMCG industries is different because of variation in shelf life of products. The food and beverages have low shelf life and requires higher frequency of purchase. It has also been observed that the many urban consumers prefer online mode to buy grocery items from different online local and national players specifically during week days. During week end times, the urban consumers favor to visit supermarkets and hypermarkets to buy grocery items. In case of household FMCG goods, highest frequency is observed in monthly purchase as the shelf life of the product is more. In case of personal care products, consumers do not like to make frequent purchase and normally build inventory of preferred brands. It has also been observed that the penetration of online platform is very high in Indian urban markets in this category.

\section{Hypothesis 2:}

The null hypothesis is rejected which indicates the consumer preferences considerably differ in mode of payment in all these three industries. In terms of first preference the first position is secured by the cash method in the all three industries. But in case of other payments option, the usage of debit and credit cards is high in personal care industry in urban markets. The usage of mobile wallet and debit card is also high in food and beverages industry.

\section{Hypothesis 3:}

The null hypothesis is rejected which indicates the frequency of usage of mobile wallets is considerably different in all three industries. Now in urban markets, specifically by youth, the mobile wallets are extensively and frequently used in food and beverages industry. The urban youth is now considerably habituated with the digital wallets.

\section{MAJOR FINDINGS AND DISCUSSION}

$\checkmark \quad$ It has been observed from primary research that the urban consumers are giving comparatively higher importance to E-commerce and M-Commerce to buy various FMCG goods as more than 60 percentage respondents have given preference to online platforms. Their overall proficiency in online platform is also high as almost 62 percentage respondents declared their high competency in usage of E-Commerce and M-Commerce platform .

$\checkmark$ Regarding reasons behind usage of mobile wallets, all the respondents have given highest importance to convenient part of mobile wallets. The second most important reason behind mobile wallets is discounts 
and offers. The corporate have done tie-ups with different industries, which are providing special discounts in the usage of mobile wallets in purchase. The respondents have given less weightage to loyalty rewards point as they assume that the monetary benefits are comparatively nominal.

$\checkmark \quad$ The respondents are satisfied with the security of the Mobile wallets application. Regarding privacy almost 63 percentage respondents have shown their concern about it and they are feeling that the companies are tracing their buying behavior for consumer profiling.

$\checkmark$ The respondents have appreciated the customer friendly features of mobile wallets apps. They are also acknowledging the need of awareness for consumers about protection of their smartphone with active security features to avoid its misuse by third party. Regarding internet and connectivity, the urban consumers are satisfied with the present telecommunication services. They have also acknowledged that this sector is now more customers' centric and corporates are putting immense efforts to provide best service with reasonable price.

$\checkmark$ It has been also observed that the limited amount of money transfer is one of the limitations in case of mobile wallets. The compatibility of operating systems in smartphone is also problem in case of few mobile wallets which are designed to operate on specific operating system only.

$\checkmark$ At retail level penetration of mobile wallets is very fast in Indian urban area. The consumers are using multiple methods for the transaction which has forced retailers to keep all the options open.

$\checkmark$ Regarding role of media in expansion of mobile wallets business in India, the primary research puts the "word of mouth communication" on the top. The urban consumers are taking support of both the platforms (i.e online/social media and offline) of "word of mouth communication" for selection of mobile wallets in different transaction. About creation of awareness, the respondents placed Television on second position and believe that the national television networks are playing important role in brand awareness and also in penetration of mobile wallet industry.

$\checkmark$ From many years, the India is known for the dual economy and cash was the primary mode for exchange. The mobile payment commenced in 2010 in India. But the real rapid expansion of this sector was started after demonetization in 2016. The privatization of banking sector has also given opportunities to foreign players to venture into Indian markets. For consolidation of banking sector, government is focusing on mergers of the banks specifically of rural areas. This development has improved the financial position of the banks and encouraging them to focus on non cash transactions.

$\checkmark$ The growth of mobile subscriber segment has also expanded the market for M-commerce in India. At present there are more than 1 billion people are using mobile phone in India.

$\checkmark$ The role of Reserve Bank of India (RBI) is critical in expansion of M-Commerce market as it issues the license for the same. To expand market of cash less economy, now banks have also implemented aggressive marketing strategies like many banks have reduced interest rate on credit card.

$\checkmark$ The other modes of transactions like RTGS, NEFT, CCIL, etc are not applicable in end users i.e consumers in FMCG sector. They are normally used in upstream and up to retailer in downstream network in FMCG supply chain networks.

$\checkmark$ To provide better security and also to gain consumer confidence, RBI has taken several measures like OTP (i.e one time password) feature is added in credit/debit card transaction.

$\checkmark$ The mobile payment market is mainly divided into three parts; Mobile Banking, Mobile POS and Mobile wallet. Recently, it has been observed that Mobile POS market is in declining stage as the consumers are switching to Mobile banking and mobile wallets specifically in urban areas.

$\checkmark \quad$ Still in India, the mobile wallets market is in infant stage and sizable numbers of segments are untapped by the companies. This has attracted foreign and national companies to form aggressive marketing strategies to catch this business opportunity. If the same growth is continued then this will capture approximately 57 percentage market share of mobile payment by financial year 2022 as per ASSOCHAM, 2016 report.

$\checkmark$ To expand market share in India, the e-commerce corporate have introduced COD (i.e Cash on delivery option). This is the main reason behind restrictive growth of mobile wallets market in India. 


\section{CONCLUSION}

The overall Indian markets are expanded after liberalization of Indian economy. The information technology insurrection is also one of the important reasons behind rapid expansion of economy. The governments, specifically central government have taken numbers of corrective measures to bring transparency in markets. The digitalization move primarily aims to reduce transaction cost and time in supply chain operations. This is well supported specifically by private banks and non banking financial institutions compared to government banks. To grab market opportunities, online businesses have also done changes in their modalities specifically for Indian markets like introduction of COD option in the transaction. This has also restricted growth of mobile wallets markets. The government has also placed amount limit in different mobile wallets option, which restricts their suitability for bulk transactions. In FMCG sector, the amount limit is not significantly touching consumers as it deals with perishable products and frequent purchase is required. It has been observed that in FMCG sector, the usage of digital wallets is high and increasing in consumable products categories i.e food and beverages in urban markets. The consumers are favoring this as it reduced their waiting time at check-out counters. In other industries like personal care products and household goods, the usage of wallets are also increasing but rate of expansion is less compared to food and beverages industries because the products are in these categories are comparatively high involvement categories. Compared to overall transaction, still the cash is dominating all these three markets. The government has placed free transaction limits in ATM withdrawal which is also encouraging consumers to use debit/credit cards and mobile wallets in their transaction. For better security in transactions, government and RBI have taken several initiatives which have boosted the confidence of consumers in non cash transactions. It has also been observed that in working women segment and also in youth segment the penetration of mobile wallet is rapid in urban consumer markets. The corporate which are operating their business in Indian markets on online and offline modes are redesigning their supply chain networks to make them more suitable for cashless transactions. Overall the future of digital wallet market is bright in Indian markets and will see exponential growth in coming years.

\section{REFERENCE LIST}

J.Mohamed Ali, Mr. L.Vijaya Gopalan (2018), E-Wallet Payment: SWOT Analysis from Customer Perception, International Journal of Recent Research Aspects ISSN: 2349-7688, Special Issue: Conscientious Computing Technologies, April 2018, pp. 155-158

Pushpa S. Abbigeri, Rajeshwari M. Shettar (2018), The Changing Trends in Payments: An Overview, International Journal of Business and Management Invention (IJBMI) ISSN (Online): 2319 - 8028, ISSN (Print): 2319 - 801X www.ijbmi.org || Volume 7 Issue 7 Ver. II || July. 2018 || PP-01-05

Sharon Devarajan, 2016, Types of Mobile Wallets and Leaders in India, Posted on December 26, 2016, Accessed on 29th November 2018, https://www.tutorialspoint.com/articles/types-of-mobile-wallets-andleaders-in-india

Srihari Kulkarni, Abdul Shahanaz Taj (2017), Digital Payments: Challenges and Solutions, IOSR Journal of Business and Management (IOSR-JBM) e-ISSN: 2278-487X, p-ISSN: 2319-7668 PP 50-55

Yashwant Raj, "India is world's sixth largest economy at \$2.6 trillion, says IMF", Hindustan Times, Apr 19, 2018 10:40 IST, Accessed on 26th September 2018, https://www.hindustantimes.com/business-news/india-isworld-s-sixth-largest-economy-at-2-6-trillion-says-imf/story-7wXZPXSWIvvImIAvpLKeNL.html

Neelmani Jaysawal and Sudeshna Saha, Urbanization in India: An Impact Assessment, International Journal of Applied Sociology 2014, 4(2): 60-65, DOI: 10.5923/j.ijas.20140402.04, Accessed on 26th September 2018, https://www.researchgate.net/publication/264383323_Urbanization_in_India_An_Impact_Assessment

\section{REFERENCES - REPORTS}

ASSOCHAM INDIA \& RNCOS (2016), "M-Wallet: Scenario post demonetisation", Accessed on 26th September 2018, http://www.assocham.org/upload/docs/M-Wallet_Report_press.pdf 
IJASOS- International E-Journal of Advances in Social Sciences, Vol. V, Issue 13, April 2019

FDI in India, India: Snapshot, Indian Brand Equity Foundation (IBEF), May 2018, Accessed on 26th September 2018, https://www.ibef.org/economy.aspx 